\title{
Symptom-level genetic modelling identifies novel risk loci and unravels the shared genetic architecture of anxiety and depression
}

\author{
Jackson G. Thorp ${ }^{\mathrm{a}, \mathrm{b}}$, Adrian I. Campos ${ }^{\mathrm{b}, \mathrm{c}}$, Andrew D. Grotzinger ${ }^{\mathrm{d}}$, Zachary Gerring ${ }^{\mathrm{a}}$, Jiyuan
}

$A n^{e}$, Jue-Sheng Onge, Wei Wang ${ }^{f}$, 23andMe Research Team $^{f}$, Suyash Shringarpure ${ }^{f}$, Enda M.

Byrneg, Stuart MacGregore, Nicholas G. Martinc, Sarah E. Medland $^{\text {h }}$, Christel M.

Middeldorp ${ }^{\mathrm{i}, \mathrm{j}, \mathrm{k}}$, Eske M. Derks ${ }^{\mathrm{a}}$

\footnotetext{
a Translational Neurogenomics, QIMR Berghofer Medical Research Institute, Brisbane, Australia

${ }^{b}$ Faculty of Medicine, University of Queensland, Brisbane, Australia

${ }^{c}$ Genetic Epidemiology, QIMR Berghofer Medical Research Institute, Brisbane, Australia

${ }^{d}$ Department of Psychology, University of Texas at Austin, Austin, United States

e Statistical Genetics, QIMR Berghofer Medical Research Institute, Brisbane, Australia

f 23andMe, Inc., Sunnyvale, United States

g Institute for Molecular Bioscience, University of Queensland, Brisbane, Australia

h Psychiatric Genetics, QIMR Berghofer Medical Research Institute, Brisbane, Australia

' Child Health Research Centre, University of Queensland, Brisbane, Australia

j Child and Youth Mental Health Service, Children's Health Queensland Hospital and Health Service, Brisbane, Australia

${ }^{k}$ Department of Biological Psychology, VU University Amsterdam, Amsterdam, The Netherlands
}

\section{Correspondence:}

Jackson Thorp

Translational Neurogenomics

300 Herston Road

Brisbane, QLD 4006

Jackson.Thorp@qimrberghofer.edu.au
Eske Derks

Translational Neurogenomics

300 Herston Road

Brisbane, QLD 4006

Eske.Derks@qimrberghofer.edu.au 
medRxiv preprint doi: https://doi.org/10.1101/2020.04.08.20057653; this version posted April 14, 2020. The copyright holder for this preprint (which was not certified by peer review) is the author/funder, who has granted medRxiv a license to display the preprint in perpetuity.

It is made available under a CC-BY-NC 4.0 International license .

2 Depression and anxiety are highly prevalent and comorbid psychiatric traits that cause

3 considerable burden worldwide. Previous studies have revealed substantial genetic overlap 4 between depression, anxiety, and a closely related personality trait - neuroticism. Here, we

5 use factor analysis and genomic structural equation modelling (Genomic SEM) to investigate 6 the genetic factor structure underlying 28 items assessing depression, anxiety and 7 neuroticism. Symptoms of depression and anxiety loaded on two distinct, although 8 genetically correlated factors, while neuroticism items were partitioned between them. We

9 leveraged this factor structure to conduct multivariate genome-wide association analyses on latent factors of anxiety symptoms and depressive symptoms, using data from over 400,000 individuals in the UK Biobank. We identified 89 independent variants for the depressive factor (61 genomic loci, 29 novel) and 102 independent variants for the anxiety factor (73 loci, 71 novel). Of these variants, $72 \%$ and $78 \%$, respectively, replicated in an independent 23 andMe cohort of $\sim 1.9$ million individuals with self-reported diagnosis of depression (634,037 cases) and anxiety $(624,615$ cases). A pairwise GWAS analysis revealed substantial genetic overlap between anxiety and depression but also showed trait-specific genetic influences; e.g. genomic regions specific to depressive symptoms were associated with hypertriglyceridemia, while regions specific to anxiety symptoms were linked to blood pressure phenotypes. The substantial genetic overlap between the two traits was further evidenced by a lack of traitspecificity in polygenic prediction of depressive and anxiety symptoms. Our results provide novel insight into the genetic architecture of depression and anxiety and comorbidity between them. 
medRxiv preprint doi: https://doi.org/10.1101/2020.04.08.20057653; this version posted April 14, 2020. The copyright holder for this preprint (which was not certified by peer review) is the author/funder, who has granted medRxiv a license to display the preprint in perpetuity. It is made available under a CC-BY-NC 4.0 International license.

3

\section{Symptom-level genetic modelling identifies novel risk loci and unravels the shared genetic architecture of anxiety and depression}

Depression and anxiety are the two most prevalent psychiatric disorders and cause substantial disease burden, accounting for over $10 \%$ of years lived with disability worldwide (Vigo, Thornicroft, and Atun 2016; World Health Organization 2017). They are highly comorbid; around three quarters of people with an anxiety disorder also meet diagnostic criteria for major depressive disorder (Lamers et al. 2011). Genetic factors play a substantial role in liability to these disorders, with heritability estimates between 30 to 40 percent for both depression and anxiety (Hettema, Neale, and Kendler 2001; Sullivan, Neale, and Kendler 2000). Twin and family studies suggest that their comorbidity is largely explained by shared genetic risk factors (Middeldorp et al. 2005).

Neuroticism, characterised as the tendency to experience emotional negativity, such as mood swings, sadness, and worry (McCrae and Costa 1985; Eysenck and Eysenck 1985), is a shared risk factor for depression and anxiety (Kotov et al. 2010; Gray and McNaughton 2000; Ormel et al. 2013; Zinbarg et al. 2016). Genetic factors explain around $\sim 40 \%$ of variation in neuroticism (Vukasović and Bratko 2015), and these factors largely overlap with those that affect depression and anxiety (Hettema, Prescott, and Kendler 2004; Jardine, Martin, and Henderson 1984; Fanous et al. 2002; Hettema et al. 2006; Middeldorp et al. 2005). Recent molecular genetic studies have uncovered extensive pleiotropy between these three traits (Purves et al. 2019; Meier et al. 2019; Wray et al. 2018), but little is known about their genetic overlap at a symptom-based level. Here, we investigate the genetic relationship between individual symptoms of anxiety, depression and neuroticism, in order to elucidate their genetic overlap and gain insight into the biological mechanisms underlying comorbidity between anxiety and depression. 
medRxiv preprint doi: https://doi.org/10.1101/2020.04.08.20057653; this version posted April 14, 2020. The copyright holder for this preprint (which was not certified by peer review) is the author/funder, who has granted medRxiv a license to display the preprint in perpetuity. It is made available under a CC-BY-NC 4.0 International license.

4

48 Genome-wide association studies (GWAS) have accelerated our progress in unravelling the genetic architecture of these psychiatric traits. The general observation is that complex traits are influenced by large numbers of genetic variants with small individual effect sizes (i.e. high polygenicity) and consequently require very large sample sizes in order to detect them.

Recent GWAS have identified over 100 independent and robustly associated single nucleotide polymorphisms (SNPs) for depression and neuroticism (Howard et al. 2019; Wray et al. 2018; Nagel, Jansen, et al. 2018; Luciano et al. 2018). In comparison, genetic studies of anxiety are still underpowered, with the largest studies to date having identified 5 genetic risk loci for lifetime anxiety disorder (Purves et al. 2019) and 6 loci for anxiety symptoms (Levey et al. 2020). While the full-scope of risk conferring genetic loci remains to be discovered for these traits, bivariate genomic methods (e.g., LD Score Regression; Bulik-Sullivan et al. 2015) have been used to obtain estimates of overall levels of genetic overlap. Consistent with familybased results, large SNP-based genetic correlations have been reported across depression, anxiety, and neuroticism ( $\left.r_{\mathrm{g}}>0.70\right)$ (Wray et al. 2018; Nagel, Jansen, et al. 2018). Moreover, pairwise comparison of genomic loci implicated in neuroticism and major depression found a substantial portion ( $70 \%$ ) of regions associated with major depression are also associated with neuroticism (Adams et al. 2019).

The extensive genetic overlap between depression, anxiety, and neuroticism may partly reflect overlap in item content and diagnostic criteria used to measure these traits (Ormel, Riese, and Rosmalen 2012). Numerous scales of neuroticism include "sub-scales" or "facets" of both depression and anxiety (e.g. NEO Personality Inventory-Revised (NEO-PI-R); California Psychological Inventory (CPI) Big Five), and many items within these scales closely resemble symptom measures of both depression and anxiety. For example, NEO-PI-R neuroticism items 
medRxiv preprint doi: https://doi.org/10.1101/2020.04.08.20057653; this version posted April 14, 2020. The copyright holder for this preprint (which was not certified by peer review) is the author/funder, who has granted medRxiv a license to display the preprint in perpetuity. It is made available under a CC-BY-NC 4.0 International license.

5

guilt or sinfulness" are very similar to the DSM-5 major depression symptom "Feelings of worthlessness or excessive or inappropriate guilt". Neuroticism is therefore not operationally distinct, implying that by studying its underlying components one could gain valuable insight into symptoms of anxiety and depression and their genetic influences. Indeed, hierarchical clustering of individual neuroticism items in the Short-form Eysenck Personality Questionnaire-Revised (EPQR-S) (Eysenck, Eysenck, and Barrett 1985) revealed two genetic item clusters, termed 'depressed affect' and 'worry', displaying stronger genetic overlap with depression and anxiety, respectively (Nagel, Watanabe, et al. 2018).

Item or symptom-level genetic analyses allow investigation of the underlying genetic structure of a trait and have proven useful in disentangling genetic and phenotypic heterogeneity of neuroticism and depression (Nagel, Watanabe, et al. 2018) (Thorp et al. 2019). In the present study, we extend this approach across multiple traits and investigate the genetic factor structure underlying 28 symptoms of depression, anxiety, and neuroticism. We apply genomic structural equation modelling (Genomic SEM) (Grotzinger et al. 2019), a recently developed multivariate method which enables estimation of the joint genetic architecture of multiple complex traits based on summary statistics from GWAS. This allows genetic subtypes or combinations of genetically similar symptoms to be identified, leading to increased statistical power for the discovery of genetic loci and improved understanding of the comorbidity and genetic overlap across traits. We sought to answer three questions: (1) how do items used to measure neuroticism genetically relate to symptoms of depression and anxiety; (2) can we leverage genetic overlap with neuroticism to boost power for the discovery of genetic risk loci for anxiety and depressive symptoms; and (3) can we identify genetic loci that differentiate anxiety and depressive symptoms? First, we model the genetic factor structure across the three traits using item-level questionnaire data from the UK 
medRxiv preprint doi: https://doi.org/10.1101/2020.04.08.20057653; this version posted April 14, 2020. The copyright holder for this preprint (which was not certified by peer review) is the author/funder, who has granted medRxiv a license to display the preprint in perpetuity. It is made available under a CC-BY-NC 4.0 International license.

6

96 Biobank (anxiety and depressive symptoms, $N=\sim 135,000$; neuroticism, $N=\sim 400,000$ ). Then,

97 we leverage this factor structure to identify genetic loci for latent factors of depressive

98 symptoms and anxiety symptoms using Genomic SEM. Finally, we identify genomic regions

99 that are unique to or shared by depressive and anxiety symptoms to gain insight into the

100 genetic architecture of these traits and the comorbidity between them. 
medRxiv preprint doi: https://doi.org/10.1101/2020.04.08.20057653; this version posted April 14, 2020. The copyright holder for this preprint (which was not certified by peer review) is the author/funder, who has granted medRxiv a license to display the preprint in perpetuity. It is made available under a CC-BY-NC 4.0 International license.

\section{Results}

104 We explored genetic overlap between anxiety symptoms, depressive symptoms, and neuroticism by modelling the genetic factor structure of items used to measure these traits.

106 Item-level genome-wide association analyses were conducted individually on each of 28 items

107 of neuroticism (12 items; EPQR-S), anxiety (7 items; GAD-7), and depression (9 items; PHQ-9), 108 in 135,000 UKB participants (see Supplementary table 1 for item-specific sample sizes). LD Score regression was used to calculate genetic correlations between all item pairs and an exploratory factor analysis (EFA) was then conducted on this genetic correlation matrix. A minimum average partial (MAP) test suggested the optimal number of factors to extract is

112 three (consistent with the eigenvalue-greater-than-one rule; see Supplementary Table 2).

113 Factor loadings of the 3-factor model are presented in Figure 1 (and Supplementary Table 3).

114 Depression items had high loadings (>0.4) on genetic factor 1 , anxiety items had high loadings on genetic factor 2 (except for the item 'irritability', which loaded onto factor 1), and

116 neuroticism items loaded either highly on factor 1 (5 items) or factor 2 (7 items). Genetic

117 factor 3 is characterised by relatively low loadings, which are positive for items of depression

118 and anxiety, and negative for items of neuroticism. The items with the highest loadings on

119 factor 3 are mostly somatic symptoms; therefore this factor may contain variance that 120 separates a psychosomatic facet of depression and anxiety from neuroticism. Factor 3 is

121 largely underpowered for further genetic analysis; we therefore restrict subsequent analyses

122 to factor 1 and factor 2 . In this paper, we refer to these two genetic latent factors as DEP 123 (depressive symptoms) and ANX (anxiety symptoms). 
medRxiv preprint doi: https://doi.org/10.1101/2020.04.08.20057653; this version posted April 14, 2020. The copyright holder for this preprint (which was not certified by peer review) is the author/funder, who has granted medRxiv a license to display the preprint in perpetuity. It is made available under a CC-BY-NC 4.0 International license.

8

124 We then submitted this factor structure model to Genomic SEM (retaining standardised

125 loadings $>0.4$ ) to assess its fit to the data (taking into account uncertainty in covariance estimates). The model provided adequate fit to the data ( $C F I=0.890 ; \mathrm{SRMR}=0.087$; factor

127 loadings in Supplementary Table 4). As a first validation of the DEP and ANX latent factors that

128 included the neuroticism items, we calculated genetic correlations between the latent factors

129 and sum-scores of depressive symptoms (PHQ-9; $N=135,149$ ) and anxiety symptoms (GAD-

$1307 ; \mathrm{N}=135,747)$. The genetic correlations between the PHQ-9 sum-score and the DEP latent

131 factor $\left(r_{g}=0.94,95 \% \mathrm{Cl}[0.87,1.01]\right)$, and the GAD-7 sum-score and ANX latent factor $\left(r_{g}=0.93\right.$,

$13295 \% \mathrm{Cl}[0.86,1.00])$ were not significantly different from one, suggesting the DEP and ANX

133 latent factors are good proxies for anxiety and depressive symptoms. The genetic correlation

134 between the DEP and ANX factors was moderately high $\left(r_{g}=0.80,95 \% \mathrm{Cl}[0.77,0.83]\right)$ and was

135 similar to the correlation between the PHQ-9 and GAD-7 sum-scores $\left(r_{\mathrm{g}}=0.83,95 \% \mathrm{Cl}\right.$

$136[0.72,0.95])$.

137 Multivariate GWAS of anxiety and depressive symptoms

138 Having identified the genetic latent factor structure within the UKB sample, our next step was

139 to leverage this structure to identify genomic risk loci for the DEP and ANX latent factors. To

140 maximise power in the multivariate GWAS, we expanded the neuroticism items to the full

141 UKB set (i.e. an additional 270k individuals who completed the neuroticism questionnaire

142 but not the depressive or anxiety symptoms questionnaires were included; each neuroticism

143 item $\mathrm{N}=\sim 400 \mathrm{k})$. We examined whether this changed the factor structure by fitting the EFA-

144 derived model to the genetic covariance matrix of the full UKB set. The EFA-derived factor

145 structure retained adequate fit to the data $(\mathrm{CFI}=0.893$; $\mathrm{SRMR}=0.088)$, while standardised

146 factor loadings were concordant with loadings before expanding the sample size of 
medRxiv preprint doi: https://doi.org/10.1101/2020.04.08.20057653; this version posted April 14, 2020. The copyright holder for this preprint (which was not certified by peer review) is the author/funder, who has granted medRxiv a license to display the preprint in perpetuity. It is made available under a CC-BY-NC 4.0 International license.

9

neuroticism ( $r=0.95$; factor loadings in Supplementary Table 5). The genetic correlation between the DEP and ANX factors remained the same $\left(r_{g}=0.79,95 \% \mathrm{Cl}[0.77,0.81]\right)$.

149 Multivariate GWAS were conducted by estimating the effects of individual SNPs on the DEP 150 and ANX latent factors using Genomic SEM. The GWAS of the DEP factor identified 7,677 genome-wide significant SNPs $\left(P<5 \times 10^{-8}\right)$, tagging 89 independent SNPs in 62 genomic risk loci (see Figure 2a and Supplementary Table 6). Of these loci, 33 overlap with a previous GWAS of depressive symptoms or major depression (Wray et al. 2018; Nagel, Jansen, et al. 2018; Howard et al. 2019; Okbay et al. 2016; Howard et al. 2018; Hyde et al. 2016; Turley et al. 2018; Baselmans et al. 2019), while 29 are novel depression loci. For the ANX factor, 11,163 SNPs reached genome-wide significance, tagging 102 independent SNPs in 73 loci (see Figure

$1572 \mathrm{2a}$ and Supplementary Table 7). Two loci overlapped with a previous GWAS of anxiety disorders (Purves et al. 2019), and 71 loci are novel for anxiety. LD Score Regression analyses

159 indicated that our GWAS results were not due to uncontrolled inflation for either DEP 160 (intercept $=0.991$, s.e. $=0.010$ ) or ANX (intercept $=1.003$, s.e. $=0.011$ ). Effect sizes of 161 independent significant SNPs showed large concordance between DEP and ANX. Three variants had significantly $\left(P<2.76 \times 10^{-4}\right)$ different effect sizes: rs613872 was associated only with DEP, and two SNPs (rs62250713 and rs391957) with ANX only (see Figure 2b).

164 We conducted a replication of the significant independent SNPs in a cohort of research participants from 23andMe with information on self-reported diagnosis of depression (634,037 cases; $1,308,690$ controls) and anxiety (624,615 cases; $1,310,854$ controls). For the DEP replication, 81 variants were tested (8 SNPs were unavailable or of insufficient quality in the 23andMe cohort). Of these variants, 58 were significant after Bonferroni correction ( $\alpha=$ $\left.0.05 / 81 ; P<6.17 \times 10^{-4}\right)$ and had the same direction of effect, and 40 reached genome-wide 
medRxiv preprint doi: https://doi.org/10.1101/2020.04.08.20057653; this version posted April 14, 2020. The copyright holder for this preprint (which was not certified by peer review) is the author/funder, who has granted medRxiv a license to display the preprint in perpetuity. It is made available under a CC-BY-NC 4.0 International license.

10

170 significance $\left(P<5 \times 10^{-8}\right) .93$ ANX variants were tested for replication (9 SNPs were of

171 insufficient quality in the 23andMe cohort), of which 73 were significant after Bonferroni

172 correction $\left(\alpha=0.05 / 93 ; P<5.38 \times 10^{-4}\right)$ and had the same direction of effect, and 39 reached

173 genome-wide significance $\left(P<5 \times 10^{-8}\right)$.

174 MAGMA was used to conduct gene-based association tests and gene-set enrichment 175 analyses. We identified 255 genes and 9 gene sets associated with DEP, and 325 genes and

17621 gene sets associated with ANX (significant after Bonferroni correction; Supplementary

177 Tables 8-11). There was substantial overlap with respect to enriched functional categories

178 between the two traits (110 genes and 5 gene sets).

\section{Polygenic risk prediction}

180 To further validate the latent factors, we used polygenic risk scores (PRS) derived from the ANX and DEP summary statistics to predict both depressive and anxiety symptoms in an independent sample $(\mathrm{N}=4,434)$. The PRS includes all SNPs, using Bayesian multiple regression to account for linkage disequilibrium (see Methods). PRS for DEP significantly predicted depressive symptoms $\left(P=2.69 \times 10^{-10}\right)$, explaining $1.05 \%$ of variance (see Figure 3 ). Similarly, PRS for ANX significantly predicted anxiety symptoms $\left(P=4.80 \times 10^{-14}\right)$, explaining $1.53 \%$ of variance. For comparison, we also calculated PRS from PHQ-9 sum-score, GAD-7 sum-score, neuroticism, major depression (Wray et al. 2018), depression (Howard et al. 2019) and anxiety disorders (Purves et al. 2019). The DEP and ANX latent factors explained a greater amount of variance than the sum-scores (proportional increase in explained variance was $185 \%$ and $237 \%$, respectively), indicating that polygenic prediction was improved by the combination of leveraging information from the neuroticism items and taking a more psychometrically informed approach (i.e., factor analysis) to phenotype construction. Overall, specificity in 
medRxiv preprint doi: https://doi.org/10.1101/2020.04.08.20057653; this version posted April 14, 2020. The copyright holder for this preprint (which was not certified by peer review) is the author/funder, who has granted medRxiv a license to display the preprint in perpetuity. It is made available under a CC-BY-NC 4.0 International license.

11

193

194

195

196

197

198

199

200

201

202

203

204

205

206

207

208

209

210

211

212

213

polygenic prediction was low; PRS for depression phenotypes explained an equal or greater amount of variance in anxiety symptoms than depressive symptoms (see Figure 3 and Supplementary Table 12).

\section{Genetic correlations with other complex traits}

We estimated genetic correlations between the ANX and DEP latent factors and a range of human complex traits (see Figure 4 and Supplementary Table 13). While patterns of correlations were similar in magnitude and direction across most of the traits, some traits showed differential genetic overlap with DEP and ANX. Smoking related phenotypes (initiation, age of initiation, cigarettes per day, and cessation) genetically correlated with DEP $\left(\left|r_{g}\right|>0.27\right)$, but not with ANX. Genetic overlap with socioeconomic traits (Townsend deprivation index, household income, and educational attainment) was consistently larger for DEP than ANX. Conversely, ANX showed stronger overlap with obsessive compulsive disorder, anorexia nervosa, and schizophrenia.

\section{Shared and trait-specific genetic influences}

We sought to identify trait-specific genomic regions by conducting a pairwise analysis of the DEP and ANX GWAS summary statistics in order to characterise regions as pleiotropic, or uniquely associated with either DEP or ANX. We used gwas-pw (Pickrell et al. 2016) to estimate the posterior probability that a given genomic region is associated with (1) DEP only, (2) ANX only, (3) both DEP and ANX, and (4) both DEP and ANX but via separate causal variants. Out of the 1703 tested regions, $123(7 \%)$ had a posterior probability greater than 0.5 of containing a causal variant for at least one of the two traits. Of these regions, 10 were uniquely associated with DEP, 20 were uniquely associated with ANX, 71 were associated with 
medRxiv preprint doi: https://doi.org/10.1101/2020.04.08.20057653; this version posted April 14, 2020. The copyright holder for this preprint (which was not certified by peer review) is the author/funder, who has granted medRxiv a license to display the preprint in perpetuity. It is made available under a CC-BY-NC 4.0 International license.

12

215

216

217

218

220

221

222

223

224

225

226

227

228

229

230

231

232

233

234

both DEP and ANX, and 22 were associated with both traits but via separate variants (see Figure 5a and Supplementary Table 14).

Next, we conducted gene-based association tests separately for regions that were specific to DEP, specific to ANX, or shared. We identified 26 genes significantly associated with DEPspecific regions, 47 genes with ANX-specific regions, and 144 with shared regions (see Supplementary Tables 15-17). To further identify genes for trait-specific and shared regions we also mapped SNPs (that reached genome-wide significance in the GWAS) to genes based on proximity, eQTL, and chromatin interactions. These three strategies mapped 49 genes to DEP-specific regions, 74 genes to ANX-specific regions and 470 genes to shared regions (see Supplementary Tables 18-20). The total number of genes identified (across all methods) was 63, 102 and 509 genes for DEP-specific, ANX-specific and shared regions, respectively (see Figure 5b).

Using all genes linked to trait-specific and shared regions, we conducted gene-set enrichment analysis against gene-sets defined by traits in the NHGRI-EBI GWAS Catalog (Buniello et al. 2019). Genes prioritised for DEP-specific regions were significantly enriched in a gene-set for hypertriglyceridemia $\left(P=1.92 \times 10^{-7}\right)$. Genes mapped to ANX-specific regions showed enrichment in multiple gene-sets: schizophrenia $\left(P=1.99 \times 10^{-11}\right)$, autism spectrum disorder or schizophrenia $\left(P=2.03 \times 10^{-22}\right)$, response to cognitive-behavioural therapy in major depressive disorder $\left(P=1.30 \times 10^{-13}\right)$, and multiple gene sets related to blood pressure: mean arterial pressure $\left(P=4.37 \times 10^{-7}\right)$, systolic blood pressure $\left(P=3.24 \times 10^{-7}\right)$, pulse pressure $\left(P=2.65 \times 10^{-7}\right)$, and hypertension $\left(P=1.27 \times 10^{-5}\right)$. Genes prioritised for shared regions were significantly enriched in 109 gene-sets (see Supplementary Table 21), including autism spectrum disorder or schizophrenia $\left(P=1.71 \times 10^{-137}\right)$, blood protein levels $\left(P=1.04 \times 10^{-40}\right)$, 
medRxiv preprint doi: https://doi.org/10.1101/2020.04.08.20057653; this version posted April 14, 2020. The copyright holder for this preprint (which was not certified by peer review) is the author/funder, who has granted medRxiv a license to display the preprint in perpetuity. It is made available under a CC-BY-NC 4.0 International license.

sarcoidosis $\left(P=7.89 \times 10^{-33}\right)$, systolic blood pressure $\left(P=3.24 \times 10^{-4}\right)$, and triglyceride levels

239 $\left(P=1.81 \times 10^{-3}\right)$ 
medRxiv preprint doi: https://doi.org/10.1101/2020.04.08.20057653; this version posted April 14, 2020. The copyright holder for this preprint (which was not certified by peer review) is the author/funder, who has granted medRxiv a license to display the preprint in perpetuity. It is made available under a CC-BY-NC 4.0 International license.

14

\section{Discussion}

242 Recent studies have revealed substantial genetic correlations between depression, anxiety,

243 and neuroticism (Wray et al. 2018; Levey et al. 2020; Howard et al. 2019; Nagel, Jansen, et al.

244 2018). The extensive genetic overlap partly reflects the overlap in items used to measure

245 these traits, which motivated us to explore the genetic factor structure underlying 28

246 symptoms of depression, anxiety, and neuroticism. Leveraging the underlying factor

247 structure, we conduct GWAS on latent factors of anxiety and depressive symptoms using data

248 from over 400,000 individuals in the UK Biobank. We identify novel and robust genetic

249 associations and present findings for the largest GWAS of anxiety to date (102 GWS

250 independent variants, $\sim 78 \%$ replicate in an independent cohort of self-reported diagnosis of

251 anxiety). We also characterise shared and trait-specific genetic influences and report on gene-

252 set analyses targeted at understanding shared and trait-specific aetiology.

Modelling the genetic factor structure of symptoms of depression, anxiety, and neuroticism

revealed two key findings. First, symptoms of anxiety and depression loaded onto different

factors, although the genetic correlation between the factors was high. This implies that while

symptoms of depression and anxiety are closely related, symptoms are genetically more

similar to symptoms within the same disorder than symptoms between disorders. This observation is consistent with a phenotypic-level network analysis of the PHQ-9 and GAD-7 items within a psychiatric sample (Beard et al. 2016), which found that symptom connections were higher within each disorder than between disorders. The large degree of genetic overlap between symptoms of anxiety and depression is in agreement with twin-based symptomlevel analyses (Kendler et al. 1987), although our results suggest some specificity of common 
medRxiv preprint doi: https://doi.org/10.1101/2020.04.08.20057653; this version posted April 14, 2020. The copyright holder for this preprint (which was not certified by peer review) is the author/funder, who has granted medRxiv a license to display the preprint in perpetuity. It is made available under a CC-BY-NC 4.0 International license.

15

factors rather than forming their own factor, suggesting that at a genetic level neuroticism is

not itself a distinct construct, and likely encapsulates (sub-clinical) symptoms of both depression and anxiety. The partitioning of neuroticism items among two distinct factors is in

267 line with the results of a hierarchical clustering analysis of the genetic correlation matrix derived from these neuroticism items when analysed in isolation (Nagel, Watanabe, et al. 2018).

By leveraging item-level genetic overlap with neuroticism, we substantially increased

271 statistical power to identify genomic risk loci for depressive and anxiety symptoms. Our GWAS 272 of depressive symptoms identified 62 genomic risk loci, of which 29 are novel. For anxiety 273 symptoms, we identified 73 genomic loci (71 novel), a substantial increase from previous 274 studies which have found 6 loci for anxiety disorders (Purves et al. 2019; Meier et al. 2019) and 6 loci for anxiety symptoms (Levey et al. 2020). The identification of a large number of 276 replicable genomic loci for anxiety unlocks the possibility of leveraging statistical genetic approaches (e.g. Mendelian randomisation or drug repositioning) which were not possible with previous anxiety GWAS. We implemented one such approach, a regional pairwise analysis, in order to disentangle the shared genetic architecture of anxiety and depression and identify trait-specific genetic loci.

Our results suggest that depression-specific genomic regions are linked to

282 hypertriglyceridemia. This is consistent with several studies that have found an association between depression and triglyceride levels (Igna, Julkunen, and Vanhanen 2011; Richter, Juckel, and Assion 2010; Akbaraly et al. 2009; Glueck et al. 1993), and previous GWAS of depression have reported significant genetic correlations with triglycerides $\left(r_{g}=0.14\right.$; Wray 
medRxiv preprint doi: https://doi.org/10.1101/2020.04.08.20057653; this version posted April 14, 2020. The copyright holder for this preprint (which was not certified by peer review) is the author/funder, who has granted medRxiv a license to display the preprint in perpetuity. It is made available under a CC-BY-NC 4.0 International license.

16

triglyceride levels, suggesting that while both depression and anxiety contain a metabolic component, this component may be larger in depression than anxiety. Conversely, genes mapped to anxiety-specific regions were enriched in gene-sets related to multiple blood pressure phenotypes. While perhaps unsurprising given increased blood pressure is a direct physiological effect of the stress response, anxiety has also been linked to increased risk of hypertension (Pan et al. 2015). Interestingly, genes unique to ANX were also enriched in a gene-set linked to response to cognitive-behavioural therapy in major depression (Rayner et al. 2019), suggesting that the presence of comorbid anxiety symptoms may influence treatment response for depression. Indeed, comorbid anxiety and major depressive disorders are associated with higher symptom severity and impairment, disorder persistence, and reduced response rates (Young, Mufson, and Davies 2006; Kessler et al. 2007; Emmanuel, Simmonds, and Tyrer 1998; Walker et al. 2000; Altamura et al. 2004). There was also significant enrichment of ANX-specific regions in schizophrenia gene-sets, consistent with a larger genetic correlation of schizophrenia with the ANX factor than with DEP factor. Anxiety symptoms are highly prevalent in patients with schizophrenia (Achim et al. 2009) and are associated with the positive symptom domain of schizophrenia (Emsley et al. 1999).

Genetic correlations with other complex traits were largely concordant in direction and magnitude across DEP and ANX. Smoking related phenotypes however, were genetically correlated with depression but not with anxiety. Observational studies on the association of smoking with anxiety and depression are largely mixed with regards to the direction of effect

307 (Fluharty et al. 2017). We find moderate genetic correlations between DEP and smoking 308 initiation, cigarettes per day, cessation (positive), and age of initiation (negative). Genetic correlations were not significant between any smoking phenotype and ANX, suggesting a unique relationship between smoking behaviour and depression. 
medRxiv preprint doi: https://doi.org/10.1101/2020.04.08.20057653; this version posted April 14, 2020. The copyright holder for this preprint (which was not certified by peer review) is the author/funder, who has granted medRxiv a license to display the preprint in perpetuity. It is made available under a CC-BY-NC 4.0 International license.

17

311 It is well established that depression and anxiety share a substantial amount of genetic

312 liability. Our results provide additional evidence for this notion, with a high genetic correlation

313 between the DEP and ANX factors $\left(r_{g}=0.80\right)$, consistent with the genetic overlap between

314 major depression and anxiety disorders in previous studies $\left(r_{g}=0.75-0.80\right)$. Further, the

315 amount of polygenic overlap (i.e., the fraction of genetic variants causally influencing both

316 traits) was considerable, with 71 out of 123 genomic regions containing a causal variant that

317 influences both traits. We note that this is likely an underestimate of the proportion of shared

318 genetic effects, as the correction for sample overlap in pairwise GWAS is conservative and

319 some truly shared genetic effects may be corrected out (Pickrell et al. 2016). Given the high

320 genetic overlap and substantial comorbidity between depression and anxiety (Kessler et al.

321 2007; Lamers et al. 2011), it is unsurprising that there was very little differentiation in

322 polygenic prediction of depressive and anxiety symptoms with PRS derived from latent

323 factors. This was not specific to the latent factors; poor specificity was also seen with PRS

324 derived from clinical depression and anxiety phenotypes (Wray et al. 2018; Purves et al.

325 2019).

326 We performed multiple analyses to validate the latent factors representing depression and

327 anxiety. First, genetic correlations between the latent factors and the PHQ-9 and GAD-7 sum-

328 scores (i.e., between the DEP factor and the sum-score of the 9 depressive symptoms, and

329 between the ANX factor and the sum-score of the 7 anxiety symptoms) were very high and

330 not significantly different from one. These correlations persisted when incorporating an

331 additional $\sim 270,000$ individuals with neuroticism information only into the latent factors.

332 Second, a substantial proportion ( $72 \%$ for DEP and $\sim 78 \%$ for ANX) of genome-wide

333 significant variants replicated in a large, independent cohort of self-reported diagnosis of 
medRxiv preprint doi: https://doi.org/10.1101/2020.04.08.20057653; this version posted April 14, 2020. The copyright holder for this preprint (which was not certified by peer review) is the author/funder, who has granted medRxiv a license to display the preprint in perpetuity. It is made available under a CC-BY-NC 4.0 International license.

18

anxiety and depression. Third, polygenic risk score analyses showed that the latent factors significantly predicted depressive and anxiety symptoms in a second independent sample.

The findings of the present study should be interpreted in light of some key limitations. The

DEP and ANX latent factors represent depressive and anxiety symptoms within a populationbased cohort. While these factors had relatively high genetic correlations with clinical phenotypes, it is likely that they do not capture the entire spectrum of genetic influences on major depression and anxiety disorders (Schwabe et al. 2019; Kendler et al. 2019; Cai et al.

341 2020). For example, the episodic nature of major depression or the persistence of generalised anxiety are not well captured by symptom questionnaires. Second, by leveraging neuroticism

343 items in the extended UKB sample, we increased statistical power to identify variants for 344 symptoms which overlap with depression and anxiety (predominately 'psychological' 345 symptoms). However, the somatic, motor, and neurovegetative symptoms characteristic of 346 major depression and anxiety disorders are not well represented in neuroticism, and consequently not within our phenotypes.

348 Over a decade of molecular genetic studies have confirmed the presence of widespread 349 pleiotropy across psychiatric disorders (Smoller et al. 2019; Lee et al. 2019; Watanabe et al. 350 2019). The substantial sharing of genetic risk factors challenges the utility of analysing discrete diagnostic categories of psychopathology defined by current classification systems (such as

352 the Diagnostic and Statistical Manual of Mental Disorders 5th edition; DSM-5) in the discovery of genetic risk loci and prediction of disease. There has been recent interest in analysing psychiatric endophenotypes as an alternative (Sanchez-Roige and Palmer 2020), with initiatives such as the Hierarchical Taxonomy of Psychopathology (HiTOP) (Waszczuk et al. 
medRxiv preprint doi: https://doi.org/10.1101/2020.04.08.20057653; this version posted April 14, 2020. The copyright holder for this preprint (which was not certified by peer review) is the author/funder, who has granted medRxiv a license to display the preprint in perpetuity. It is made available under a CC-BY-NC 4.0 International license.

19

357 Symptom-level analyses are one such endophenotypic approach which may prove useful in

358 in advancing our understanding of the genetic aetiology of psychopathology, by allowing the

359 discovery of symptom-specific genetic influences and the identification of genetic subtypes

360 and trans-diagnostic factors of genetic liability. We show that analysing genetically

361 homogenous combinations of symptoms across traits can increase statistical power to

362 identify loci and elucidate comorbidity and genetic overlap between psychiatric phenotypes. 
medRxiv preprint doi: https://doi.org/10.1101/2020.04.08.20057653; this version posted April 14, 2020. The copyright holder for this preprint (which was not certified by peer review) is the author/funder, who has granted medRxiv a license to display the preprint in perpetuity. It is made available under a CC-BY-NC 4.0 International license .

20

\section{Methods}

\section{UK Biobank}

366 Data for the main analyses came from the UK Biobank (UKB), a major health data resource

367 containing phenotypic information on a wide range of health-related measures and

368 characteristics in over 500,000 participants from the United Kingdom general population

369 (Bycroft et al. 2018). Participants were excluded from the present study based on ancestry,

370 relatedness and withdrawn consent. Participants were included if they were of white British

371 ancestry, identified through self-reported ethnicity and ancestral principal components.

372 Participants who self-reported as not white British, but for whom the first two genetic

373 principal components indicated them to be genetically similar to those of white British

374 ancestry were also included in order to maximise sample size (MacGregor et al. 2018).

\section{Depressive and anxiety symptoms}

376 Depressive symptoms were assessed with the 9-item Patient Health Questionnaire (PHQ-9)

377 (Kroenke, Spitzer, and Williams 2001), and anxiety symptoms with the 7-item Generalised

378 Anxiety Disorder scale (GAD-7) (Spitzer et al. 2006). Over 150,000 participants completed the

PHQ-9 and GAD-7 as part of a UKB mental health follow-up questionnaire administered online in 2016 (Davis et al. 2020). Each item assesses the frequency of a particular symptom over the past two weeks, rated on a four-point ordinal scale: (0) not at all, (1) several days, (2) more than half the days, (3) nearly every day.

The ordinal scale of measurement of these items complicates interpretation of SNP-based heritability ( $h^{2}$ SNP) estimates. As $h^{2}$ SNP estimates are utilised in Genomic SEM, we transformed each item into a binary phenotype in order for interpretable $h^{2}$ sNP estimates to be produced. 
medRxiv preprint doi: https://doi.org/10.1101/2020.04.08.20057653; this version posted April 14, 2020. The copyright holder for this preprint (which was not certified by peer review) is the author/funder, who has granted medRxiv a license to display the preprint in perpetuity. It is made available under a CC-BY-NC 4.0 International license.

21

was one or greater (several days, more than half the days, or nearly every day), and not

endorsed if the score was zero (not at all). A cut-off score of one was used in order to maximise the number of participants who endorsed an item and hence statistical power (genetic correlations between the ordinal-scale items and binary items were all > 0.95; median $\left.r_{g}=0.98\right)$.

\section{Neuroticism}

Neuroticism was measured using the 12-item Eysenck Personality Questionnaire-Revised dichotomous scale ('yes' or 'no'). The questionnaire was administered to the entire UKB cohort ( 500,000 participants).

\section{Genome-wide association analyses}

398 GWAS analyses of the 28 individual items ( 9 depression items, 7 anxiety items, 12 neuroticism

399 items) were conducted via logistic regression in PLINK v2.00a (Chang et al. 2015). If two 400 individuals in the sample were related (pi-hat $>0.2$ ) one individual was removed 401 (preferentially from the control set if the related individuals were in both case and control sets). GWAS analyses of the PHQ-9, GAD-7, and EPQR-S sum-scores were conducted via linear

403 regression. Analyses were limited to autosomal SNPs with high imputation quality score (INFO 404 score $\geq 0.80$ ) and a minor allele frequency of $1 \%$ or higher, resulting in $9,417,325$ SNPs being 405 tested for association. Age, sex, genotyping array, and 20 principal components were 406 included as covariates.

\section{Factor analysis}

408 We first explored the genetic factor structure by conducting an exploratory factor analysis 409 (EFA) based on the genetic correlation matrix of the 28 items. The EFA was conducted using 
medRxiv preprint doi: https://doi.org/10.1101/2020.04.08.20057653; this version posted April 14, 2020. The copyright holder for this preprint (which was not certified by peer review) is the author/funder, who has granted medRxiv a license to display the preprint in perpetuity. It is made available under a CC-BY-NC 4.0 International license.

22

410 only participants who completed the UKB mental health questionnaire ( $\mathrm{N}$ range $=132,602-$

411 137,461; see Supplementary Table 1 for item-specific sample sizes). As participants who 412 completed the UKB mental health questionnaire differ significantly from the entire UKB

413 cohort (e.g. higher educational attainment, higher socio-economic status, lower rates of

414 smoking; Davis et al. 2020), we restricted the EFA to a subset for neuroticism to ensure these

415 systematic differences did not bias the EFA. Cross-trait LD Score Regression was used to

416 estimate genetic correlations between each of the 28 items. These estimates are not biased

417 by sample overlap (Bulik-Sullivan et al. 2015). The 'psych' R package was used to conduct the

418 EFA, with an ordinary least squares extraction method and oblimin rotation method. Two

419 procedures were used to decide on the optimal number of factors to extract: (1) a minimum

420 average partial (MAP) test (Velicer 1976) (the lowest average squared partial correlation

421 indicates the number of factors to extract), and the eigenvalue-greater-than-one rule (Kaiser

422 1960) (factors with an eigenvalue above 1 are extracted).

423 The factor model identified using EFA (retaining factor loadings $>0.4$ ) were subsequently

424 carried forward in a confirmatory factor analysis (CFA) in Genomic SEM (Grotzinger et al.

425 2019). This was done to assess the fit of the factor model to the data while taking into account

426 uncertainty in covariance estimates, and to allow the estimation of genetic correlations

427 between latent factors and external traits (i.e. PHQ-9 and GAD-7 sum-scores). The default

428 Diagonally Weighted Least Squares (DWLS) estimator was used. SNP-based heritability

429 estimates (diagonal of the genetic covariance matrix) were converted to the liability scale,

430 where the population prevalence of the items was estimated from the UKB sample

431 (population prevalence $=$ sample prevalence; see Supplementary Table 1). 
medRxiv preprint doi: https://doi.org/10.1101/2020.04.08.20057653; this version posted April 14, 2020. The copyright holder for this preprint (which was not certified by peer review) is the author/funder, who has granted medRxiv a license to display the preprint in perpetuity. It is made available under a CC-BY-NC 4.0 International license.

23

433

434 GWAS of the latent factors of anxiety and depressive symptoms were conducted in Genomic

SEM. All summary statistics were standardized with respect to the variance in the phenotype

436

437

(i.e., STDY) using the sumstats function in Genomic SEM. The factor structure identified in the

438

EFA was specified as the model. SNPs tested for association in the univariate item-level GWAS

and also contained in the 1000 genomes phase 3 reference sample (with MAF > 0.01) were

439

included, resulting in the analysis of 7,746,079 SNPs. We applied the conventional genome-

440

wide significance threshold of $P<5 \times 10^{-8}$.

441 The results were annotated using FUMA (Watanabe et al. 2017). Significant SNPs were

442 clumped into blocks high in linkage disequilibrium (the non-random association of alleles at a

443 specific locus; LD) using a threshold of $r^{2}<0.10$ (correlation between allele frequencies of two

444 SNPs). Genomic risk loci were identified by merging independent SNPs if $r^{2} \geq 0.10$ and their

445 LD blocks were physically close to each other at a distance of $1000 \mathrm{~kb}$.

\section{3andMe replication cohort}

447 In the 23andMe replication analysis, case-control status was determined by self-reported 448 depression (634,037 cases; $1,308,690$ controls) or self-reported anxiety $(624,615$ cases;

$4491,310,854$ controls) from samples of European ancestry (close relatives removed) in the 450 23andMe research cohort. The self-reported phenotype of depression was defined as cases

451 if samples have ever been diagnosed with depression, or controls if samples have never been

452 diagnosed with depression; the self-reported phenotype of anxiety was defined as cases if samples have ever been diagnosed with anxiety, or controls if samples have never been diagnosed with anxiety. All individuals included in the analyses provided informed consent 
medRxiv preprint doi: https://doi.org/10.1101/2020.04.08.20057653; this version posted April 14, 2020. The copyright holder for this preprint (which was not certified by peer review) is the author/funder, who has granted medRxiv a license to display the preprint in perpetuity. It is made available under a CC-BY-NC 4.0 International license.

24

455

456

457

458

459

460

461

462

463

464

465

466

467

468

469

470

471

472

473

474

475

476

477

and participated in the research online, under a protocol approved by the external AAHRPPaccredited IRB, Ethical \& Independent Review Services (http://www.eandireview.com).

Association analyses were conducted by $23 \mathrm{andMe}$; a logistic regression assuming an additive model for allelic effects was used with adjustment for age, sex, indicator variables to represent the genotyping platforms and the first five genotype principal components. The summary statistics were provided for independent genome-wide significant SNPs in the depression and anxiety latent factors GWAS. In the replication analysis of self-reported depression, 8 SNPs were unavailable or of insufficient quality in the replication sample, therefore 81 variants were tested for replication. In the replication analysis of self-reported anxiety, 9 SNPs were of insufficient quality or unavailable in the replication samples, therefore 93 variants were tested for replication.

\section{Polygenic risk prediction}

The target sample consisted of an adult cohort $(\mathrm{N}=4,434)$ from the Australian Twin Registry. Depressive and anxiety symptoms were assessed by the Delusions-Symptoms-States Inventory: Anxiety and Depression Scales (DSSI/SAD) (Bedford, Foulds, and Sheffield 1976), which consists of seven anxiety and seven depression items. Each item assesses the degree of distress due to a particular symptom, rated on a four-point ordinal scale: (0) none, (1) a little, (2) a lot, (3) unbearably. Additional details of the cohort and assessment procedures are reported elsewhere (Jardine, Martin, and Henderson 1984).

In total, nine polygenic risk scores (PRS) were created, using SNP weights from: DEP latent factor (UKB), ANX latent factor (UKB), PHQ-9 sum-score (UKB; $N=135,149$ ), GAD-7 sum-score (UKB; $N=135,747)$, neuroticism (UKB - MHQ subset; $N=136,212$ ), neuroticism (UKB; $N=$ 338,812), major depression (Wray et al. 2018 - QIMR and 23andMe cohorts excluded; $N=$ 
medRxiv preprint doi: https://doi.org/10.1101/2020.04.08.20057653; this version posted April 14, 2020. The copyright holder for this preprint (which was not certified by peer review) is the author/funder, who has granted medRxiv a license to display the preprint in perpetuity. It is made available under a CC-BY-NC 4.0 International license.

25

478

479

480

481

482

483

484

485

486

487

488

489

490

491

492

493

494

495

496

497

159,598), depression (Howard et al. 2019 - QIMR and 23andMe cohorts excluded; $N=$ 494,258), and anxiety disorders (Purves et al. 2019; $N=114,019)$. We used SBayesR (LloydJones et al. 2019) to account for the correlation in effect sizes arising from linkage disequilibrium (LD). Briefly, SBayesR implements Bayesian multiple regression to jointly analyse all SNPs and account for LD between SNPs. As recommended, a shrunk matrix derived from $\sim 3$ million SNPs (MAF > 0.01) on 50k participants from the UKB was used as the LD correlation matrix. Polygenic risk scores were calculated in PLINK v1.90 (Purcell et al. 2007). For each set of PRS we estimated the proportion of variance explained by the PRS in sumscores of both anxiety symptoms and depressive symptoms in the target sample, using genomic restricted maximum likelihood (GCTA-GREML) in order to account for relatedness within the target sample. We also estimated the amount of variance explained by PRS in logtransformed and inverse normal-transformed sum-scores of depressive and anxiety symptoms (presented in Supplementary Table 12).

\section{Gene-based tests and gene-set analysis}

MAGMA v1.07 (de Leeuw et al. 2015) was used to conduct gene-based and gene-set analyses on the summary statistics of the DEP and ANX latent factors. The gene-based analysis tested 18,756 protein coding genes for association. A Bonferroni corrected significance threshold was applied $\left(P<2.67 \times 10^{-6}\right)$. The gene-set analysis tested 7,250 gene sets for association with DEP and ANX factors. A Bonferroni corrected significance threshold was applied $\left(P<6.90 \times 10^{-6}\right)$

\section{Pairwise analysis of GWAS summary statistics}

The pairwise GWAS analysis was implemented using gwas-pw (Pickrell et al. 2016). First, the genome is split into 1703 approximately independent regions (Berisa and Pickrell 2016). Then 
medRxiv preprint doi: https://doi.org/10.1101/2020.04.08.20057653; this version posted April 14, 2020. The copyright holder for this preprint (which was not certified by peer review) is the author/funder, who has granted medRxiv a license to display the preprint in perpetuity. It is made available under a CC-BY-NC 4.0 International license.

26

501 the posterior probability of each of the following models is calculated: (1) the region is

502 associated with DEP only, (2) the region is associated with ANX only, (3) the region is 503 associated with both DEP and ANX, and (4) there are separate associations for ANX and DEP

504 within that region. To account for sample overlap across the two traits, gwas-pw requires the 505 correlation between effect sizes in the two traits in non-associated regions. We used fgwas

506 (Pickrell et al. 2014) to calculate the posterior probability of association (PPA) for each region

507 with both traits. We then calculated the correlation in effect sizes for SNPs in regions with a 508 PPA $<0.2$ for both ANX and DEP. Given one of the models has a posterior probability $>0.5$,

509 we report the model with the highest posterior probability. Results are presented in the form 510 of an ideogram, created in the Complex-Traits Genetics Virtual Lab (Cuéllar-Partida et al. 511 2019).

\section{Gene-mapping of trait-specific or shared regions}

513 First, MAGMA was used to conduct gene-based tests separately on genomic regions reported

514 to be associated with only DEP (120 protein-coding genes tested; Bonferroni corrected 515 significance threshold, $P<4.17 \times 10^{-4}$ ), regions associated with only ANX (390 protein-coding 516 genes tested; Bonferroni corrected significance threshold, $P<1.57 \times 10^{-4}$ ), and regions 517 associated with both ANX and DEP (1038 protein-coding genes tested; Bonferroni corrected 518 significance threshold, $\left.P<4.82 \times 10^{-5}\right)$.

519 Three additional methods implemented in FUMA were used to map SNPs in trait-specific or 520 shared regions (GWAS $P<5 \times 10^{-8}$ ) to genes. (1) Positional mapping: SNPs are mapped to 521 genes based on proximity (within a 10kb window). (2) eQTL mapping: SNPs are mapped to a 522 gene if they have a significant $($ FDR $<0.05)$ association with the expression level of that gene. 523 We used eQTL information from GTEx v8 (Lonsdale et al. 2013), the CommonMind 
medRxiv preprint doi: https://doi.org/10.1101/2020.04.08.20057653; this version posted April 14, 2020. The copyright holder for this preprint (which was not certified by peer review) is the author/funder, who has granted medRxiv a license to display the preprint in perpetuity. It is made available under a CC-BY-NC 4.0 International license.

27

524 Consortium (Fromer et al. 2016), and BRAINEAC (Ramasamy et al. 2014). (3) Chromatin

525 interaction mapping: genes are mapped if there is a significant (FDR $<1 \times 10^{-6}$ ) chromatin

526 interaction between a genomic region (within a genomic risk locus) and promotor regions of

527 genes $250 \mathrm{bp}$ upstream and $500 \mathrm{bp}$ downstream of the transcription start site. Hi-C sequence

528 data was used to identify chromatin interactions from 23 human tissue and cell types (Schmitt

529 et al. 2016).

530 All prioritised genes for trait-specific and shared regions were used to conduct gene-set

531 enrichment analyses (hypergeometric test performed in FUMA) against gene-sets defined by

532 traits in the NHGRI-EBI GWAS Catalog (Buniello et al. 2019). Multiple testing was corrected

533 for with a Benjamini-Hochberg false discovery rate (FDR) of 0.05. 
medRxiv preprint doi: https://doi.org/10.1101/2020.04.08.20057653; this version posted April 14, 2020. The copyright holder for this preprint (which was not certified by peer review) is the author/funder, who has granted medRxiv a license to display the preprint in perpetuity. It is made available under a CC-BY-NC 4.0 International license.

28

\section{Acknowledgements}

536 We thank the research participants of all cohorts for making this study possible. This work

537 was conducted using the UK Biobank Resource (application number 25331). NGM received

538 funding from the Australian National Health \& Medical Research Council (NHMRC) to conduct

539 surveys in the Australian Twin Registry. SM is supported by an NHMRC Fellowship.

540 Members of the 23andMe Research Team include: Michelle Agee, Stella Aslibekyan, Adam

541 Auton, Robert K. Bell, Katarzyna Bryc, Sarah K. Clark, Sayantan Das, Sarah L. Elson, Kipper

542 Fletez-Brant, Pierre Fontanillas, Nicholas A. Furlotte, Pooja M. Gandhi, Karl Heilbron, Barry

543 Hicks, David A. Hinds, Karen E. Huber, Ethan M. Jewett, Yunxuan Jiang, Kira Kalkus, Aaron

544 Kleinman, Keng-Han Lin, Nadia K. Litterman, Marie K. Luff, Matthew H. Mclntyre, Kimberly F.

545 McManus, Steven J. Micheletti, Sahar V. Mozaffari, Joanna L. Mountain, Priyanka

546 Nandakumar, Elizabeth S. Noblin, Carrie A.M. Northover, Jared O'Connell, Aaron A.

547 Petrakovitz, Steven J. Pitts, G. David Poznik, J. Fah Sathirapongsasuti, Janie F. Shelton, Chao

548 Tian, Joyce Y. Tung, Robert J. Tunney, Vladimir Vacic, and Xin Wang.

549 Conflict of interest

550 The authors have no conflicts of interest to declare. 
medRxiv preprint doi: https://doi.org/10.1101/2020.04.08.20057653; this version posted April 14, 2020. The copyright holder for this preprint (which was not certified by peer review) is the author/funder, who has granted medRxiv a license to display the preprint in perpetuity. It is made available under a CC-BY-NC 4.0 International license.

\section{References}

Achim, Amélie M., Michel Maziade, Éric Raymond, David Olivier, Chantal Mérette, and Marc-André Roy. 2009. 'How Prevalent Are Anxiety Disorders in Schizophrenia? A Meta-Analysis and Critical Review on a Significant Association', Schizophrenia Bulletin, 37: 811-21.

Adams, Mark J., David M. Howard, Michelle Luciano, Toni-Kim Clarke, Gail Davies, W. David Hill, ... Andrew M. McIntosh. 2019. 'Genetic stratification of depression by neuroticism: revisiting a diagnostic tradition', Psychological Medicine: 1-10.

Akbaraly, Tasnime N., Mika Kivimäki, Eric J. Brunner, Tarani Chandola, Michael G. Marmot, Archana Singh-Manoux, and Jane E. Ferrie. 2009. 'Association Between Metabolic Syndrome and Depressive Symptoms in Middle-Aged Adults', Diabetes Care, 32: 499.

Altamura, A. C., C. Montresor, D. Salvadori, and E. Mundo. 2004. 'Does comorbid subthreshold anxiety affect clinical presentation and treatment response in depression? A preliminary 12-month naturalistic study', Int J Neuropsychopharmacol, 7: 481-7.

Baselmans, B. M. L., R. Jansen, H. F. Ip, J. van Dongen, A. Abdellaoui, M. P. van de Weijer, ... M. Bartels. 2019. 'Multivariate genome-wide analyses of the well-being spectrum', Nat Genet, 51: 44551.

Beard, C., A. J. Millner, M. J. Forgeard, E. I. Fried, K. J. Hsu, M. T. Treadway, . . T. Bjorgvinsson. 2016. 'Network analysis of depression and anxiety symptom relationships in a psychiatric sample', Psychol Med, 46: 3359-69.

Bedford, A., G. A. Foulds, and B. F. Sheffield. 1976. 'A new personal disturbance scale (DSSI/sAD)', Br J Soc Clin Psychol, 15: 387-94.

Berisa, T., and J. K. Pickrell. 2016. 'Approximately independent linkage disequilibrium blocks in human populations', Bioinformatics, 32: 283-5.

Bulik-Sullivan, Brendan K, Hilary K. Finucane, Verneri Anttila, Alexander Gusev, Felix R. Day, Po-Ru Loh, ... Benjamin M. Neale. 2015. 'An atlas of genetic correlations across human diseases and traits', Nature Genetics, 47: 1236.

Buniello, A., J. A. L. MacArthur, M. Cerezo, L. W. Harris, J. Hayhurst, C. Malangone, . . H. Parkinson. 2019. 'The NHGRI-EBI GWAS Catalog of published genome-wide association studies, targeted arrays and summary statistics 2019', Nucleic Acids Res, 47: D1005-d12.

Bycroft, Clare, Colin Freeman, Desislava Petkova, Gavin Band, Lloyd T. Elliott, Kevin Sharp, ... Jonathan Marchini. 2018. 'The UK Biobank resource with deep phenotyping and genomic data', Nature, 562: 203-09.

Cai, Na, Joana A. Revez, Mark J. Adams, Till F. M. Andlauer, Gerome Breen, Enda M. Byrne, ... M. D. D. Working Group of the Psychiatric Genomics Consortium. 2020. 'Minimal phenotyping yields genome-wide association signals of low specificity for major depression', Nature Genetics.

Chang, Christopher C., Carson C. Chow, Laurent Cam Tellier, Shashaank Vattikuti, Shaun M. Purcell, and James J. Lee. 2015. 'Second-generation PLINK: rising to the challenge of larger and richer datasets', GigaScience, 4: 7-7.

Cuéllar-Partida, Gabriel, Mischa Lundberg, Pik Fang Kho, Shannon D'Urso, Luis F. GutiérrezMondragón, Trung Thanh Ngo, and Liang-Dar Hwang. 2019. 'Complex-Traits Genetics Virtual Lab: A community-driven web platform for post-GWAS analyses', bioRxiv: 518027.

Davis, Katrina A. S., Jonathan R. I. Coleman, Mark Adams, Naomi Allen, Gerome Breen, Breda Cullen, . .. Matthew Hotopf. 2020. 'Mental health in UK Biobank - development, implementation and results from an online questionnaire completed by 157366 participants: a reanalysis', BJPsych Open, 6: e18.

de Leeuw, Christiaan A., Joris M. Mooij, Tom Heskes, and Danielle Posthuma. 2015. 'MAGMA: Generalized Gene-Set Analysis of GWAS Data', PLOS Computational Biology, 11: e1004219.

Emmanuel, J., S. Simmonds, and P. Tyrer. 1998. 'Systematic review of the outcome of anxiety and depressive disorders', British Journal of Psychiatry, 173: 35-41. 
medRxiv preprint doi: https://doi.org/10.1101/2020.04.08.20057653; this version posted April 14, 2020. The copyright holder for this preprint

(which was not certified by peer review) is the author/funder, who has granted medRxiv a license to display the preprint in perpetuity. It is made available under a CC-BY-NC 4.0 International license.

Emsley, R. A., P. P. Oosthuizen, A. F. Joubert, M. C. Roberts, and D. J. Stein. 1999. 'Depressive and anxiety symptoms in patients with schizophrenia and schizophreniform disorder', J Clin Psychiatry, 60: 747-51.

Eysenck, Hans J, and Michael W Eysenck. 1985. Personality and individual differences: A natural science approach (Plenum: New York, NY).

Eysenck, S. B. G., H. J. Eysenck, and Paul Barrett. 1985. 'A revised version of the psychoticism scale', Personality and Individual Differences, 6: 21-29.

Fanous, A., C. O Gardner, C. A Prescott, R. Cancro, and K. S Kendler. 2002. 'Neuroticism, major depression and gender: a population-based twin study', Psychological Medicine, 32: 719-28.

Fromer, Menachem, Panos Roussos, Solveig K. Sieberts, Jessica S. Johnson, David H. Kavanagh, Thanneer M. Perumal, . . Pamela Sklar. 2016. 'Gene expression elucidates functional impact of polygenic risk for schizophrenia', Nature Neuroscience, 19: 1442.

Glueck, Charles J., Murray Tieger, Robert Kunkel, Trent Tracy, James Speirs, Patricia Streicher, and Ellen Illig. 1993. 'Improvement in symptoms of depression and in an index of life stressors accompany treatment of severe hypertriglyceridemia', Biological Psychiatry, 34: 240-52.

Gray, Jeffrey A., and Neil McNaughton. 2000. The Neuropsychology of Anxiety. An Enquiry into the Functions of the Septo-Hippocampal System (Oxford University Press: Oxford).

Grotzinger, Andrew D., Mijke Rhemtulla, Ronald de Vlaming, Stuart J. Ritchie, Travis T. Mallard, W. David Hill, . . . Elliot M. Tucker-Drob. 2019. 'Genomic structural equation modelling provides insights into the multivariate genetic architecture of complex traits', Nature Human Behaviour, 3: 513-25.

Hettema, J. M., M. C. Neale, and K. S. Kendler. 2001. 'A review and meta-analysis of the genetic epidemiology of anxiety disorders', Am J Psychiatry, 158: 1568-78.

Hettema, J. M., M. C. Neale, J. M. Myers, C. A. Prescott, and K. S. Kendler. 2006. 'A population-based twin study of the relationship between neuroticism and internalizing disorders', Am J Psychiatry, 163: 857-64.

Hettema, J. M., C. A. Prescott, and K. S. Kendler. 2004. 'Genetic and environmental sources of covariation between generalized anxiety disorder and neuroticism', Am J Psychiatry, 161: 1581-7.

Howard, David M., Mark J. Adams, Toni-Kim Clarke, Jonathan D. Hafferty, Jude Gibson, Masoud Shirali, ... Major Depressive Disorder Working Group of the Psychiatric Genomics Consortium. 2019. 'Genome-wide meta-analysis of depression identifies 102 independent variants and highlights the importance of the prefrontal brain regions', Nature Neuroscience.

Howard, David M., Mark J. Adams, Masoud Shirali, Toni-Kim Clarke, Riccardo E. Marioni, Gail Davies, . .. Andrew M. McIntosh. 2018. 'Genome-wide association study of depression phenotypes in UK Biobank identifies variants in excitatory synaptic pathways', Nature Communications, 9: 1470.

Hyde, Craig L., Michael W. Nagle, Chao Tian, Xing Chen, Sara A. Paciga, Jens R. Wendland, ... Ashley R. Winslow. 2016. 'Identification of 15 genetic loci associated with risk of major depression in individuals of European descent', Nature Genetics, 48: 1031.

Igna, C. V., J. Julkunen, and H. Vanhanen. 2011. 'Vital exhaustion, depressive symptoms and serum triglyceride levels in high-risk middle-aged men', Psychiatry Res, 187: 363-9.

Insel, Thomas, Bruce Cuthbert, Marjorie Garvey, Robert Heinssen, Daniel S Pine, Kevin Quinn, ... Philip Wang. 2010. "Research domain criteria (RDoC): toward a new classification framework for research on mental disorders." In.: Am Psychiatric Assoc.

Jardine, R., N. G. Martin, and A. S. Henderson. 1984. 'Genetic covariation between neuroticism and the symptoms of anxiety and depression', Genetic Epidemiology, 1: 89-107.

Kaiser, Henry F. 1960. 'The application of electronic computers to factor analysis', Educational and psychological measurement, 20: 141-51.

Kendler, K. S., A. C. Heath, N. G. Martin, and L. J. Eaves. 1987. 'Symptoms of anxiety and symptoms of depression. Same genes, different environments?', Arch Gen Psychiatry, 44: 451-7. 
medRxiv preprint doi: https://doi.org/10.1101/2020.04.08.20057653; this version posted April 14, 2020. The copyright holder for this preprint (which was not certified by peer review) is the author/funder, who has granted medRxiv a license to display the preprint in perpetuity. It is made available under a CC-BY-NC 4.0 International license.

31

Kendler, Kenneth S., Charles O. Gardner, Michael C. Neale, Steve Aggen, Andrew Heath, Lucía ColodroConde, ... Nathan A. Gillespie. 2019. 'Shared and specific genetic risk factors for lifetime major depression, depressive symptoms and neuroticism in three population-based twin samples', Psychological Medicine, 49: 2745-53.

Kessler, R. C, M. Gruber, J. M Hettema, I. Hwang, N. Sampson, and K. A Yonkers. 2007. 'Co-morbid major depression and generalized anxiety disorders in the National Comorbidity Survey follow-up', Psychological Medicine, 38: 365-74.

Kotov, Roman, Wakiza Gamez, Frank Schmidt, and David Watson. 2010. 'Linking "big" personality traits to anxiety, depressive, and substance use disorders: a meta-analysis', Psychological bulletin, 136: 768.

Kroenke, Kurt, Robert L. Spitzer, and Janet B. W. Williams. 2001. 'The PHQ-9', Journal of General Internal Medicine, 16: 606-13.

Lamers, Femke, Patricia Oppen, Hannie Comijs, Johannes Smit, Philip Spinhoven, Anton Balkom, ... B. W. Penninx. 2011. 'Comorbidity Patterns of Anxiety and Depressive Disorders in a Large Cohort Study: the Netherlands Study of Depression and Anxiety (NESDA)', J Clin Psychiatry, 72: 341-8.

Lee, Phil H., Verneri Anttila, Hyejung Won, Yen-Chen A. Feng, Jacob Rosenthal, Zhaozhong Zhu, ... Jordan W. Smoller. 2019. 'Genomic Relationships, Novel Loci, and Pleiotropic Mechanisms across Eight Psychiatric Disorders', Cell, 179: 1469-82.e11.

Levey, Daniel F., Joel Gelernter, Renato Polimanti, Hang Zhou, Zhongshan Cheng, Mihaela Aslan, ... Murray B. Stein. 2020. 'Reproducible Genetic Risk Loci for Anxiety: Results From 200,000 Participants in the Million Veteran Program', American Journal of Psychiatry: appi.ajp.2019.19030256.

Lloyd-Jones, Luke R., Jian Zeng, Julia Sidorenko, Loïc Yengo, Gerhard Moser, Kathryn E. Kemper, . . . Peter M. Visscher. 2019. 'Improved polygenic prediction by Bayesian multiple regression on summary statistics', Nature Communications, 10: 5086.

Lonsdale, John, Jeffrey Thomas, Mike Salvatore, Rebecca Phillips, Edmund Lo, Saboor Shad, ... Helen F. Moore. 2013. 'The Genotype-Tissue Expression (GTEx) project', Nature Genetics, 45: 580.

Luciano, Michelle, Saskia P. Hagenaars, Gail Davies, W. David Hill, Toni-Kim Clarke, Masoud Shirali, . . . Ian J. Deary. 2018. 'Association analysis in over 329,000 individuals identifies 116 independent variants influencing neuroticism', Nature Genetics, 50: 6-11.

MacGregor, S., J. S. Ong, J. An, X. Han, T. Zhou, O. M. Siggs, . . A. W. Hewitt. 2018. 'Genome-wide association study of intraocular pressure uncovers new pathways to glaucoma', Nat Genet, 50: 1067-71.

McCrae, Robert R., and Paul T. Costa. 1985. 'Updating Norman's "adequacy taxonomy": Intelligence and personality dimensions in natural language and in questionnaires', Journal of Personality and Social Psychology, 49: 710-21.

Meier, Sandra M., Kalevi Trontti, Kirstin L. Purves, Thomas Damm Als, Jakob Grove, Mikaela Laine, ... Ole Mors. 2019. 'Genetic Variants Associated With Anxiety and Stress-Related Disorders: A Genome-Wide Association Study and Mouse-Model Study', JAMA Psychiatry, 76: 924-32.

Middeldorp, C. M., D. C. Cath, R. Van Dyck, and D. I. Boomsma. 2005. 'The co-morbidity of anxiety and depression in the perspective of genetic epidemiology. A review of twin and family studies', Psychol Med, 35: 611-24.

Nagel, Mats, Philip R. Jansen, Sven Stringer, Kyoko Watanabe, Christiaan A. de Leeuw, Julien Bryois, . . . Team andMe Research. 2018. 'Meta-analysis of genome-wide association studies for neuroticism in 449,484 individuals identifies novel genetic loci and pathways', Nature Genetics, 50: 920-27.

Nagel, Mats, Kyoko Watanabe, Sven Stringer, Danielle Posthuma, and Sophie van der Sluis. 2018. 'Item-level analyses reveal genetic heterogeneity in neuroticism', Nature Communications, 9: 905. 
medRxiv preprint doi: https://doi.org/10.1101/2020.04.08.20057653; this version posted April 14, 2020. The copyright holder for this preprint

(which was not certified by peer review) is the author/funder, who has granted medRxiv a license to display the preprint in perpetuity. It is made available under a CC-BY-NC 4.0 International license.

Okbay, Aysu, Bart M. L. Baselmans, Jan-Emmanuel De Neve, Patrick Turley, Michel G. Nivard, Mark Alan Fontana, ... David Cesarini. 2016. 'Genetic variants associated with subjective well-being, depressive symptoms, and neuroticism identified through genome-wide analyses', Nature Genetics, 48: 624.

Ormel, Johan, Bertus F. Jeronimus, Roman Kotov, Harriëtte Riese, Elisabeth H. Bos, Benjamin Hankin, ... Albertine J. Oldehinkel. 2013. 'Neuroticism and common mental disorders: meaning and utility of a complex relationship', Clinical psychology review, 33: 686-97.

Ormel, Johan, Harriëtte Riese, and Judith G. M. Rosmalen. 2012. 'Interpreting neuroticism scores across the adult life course: immutable or experience-dependent set points of negative affect?', Clinical psychology review, 32: 71-79.

Pan, Yu, Wenpeng Cai, Qi Cheng, Wei Dong, Ting An, and Jin Yan. 2015. 'Association between anxiety and hypertension: a systematic review and meta-analysis of epidemiological studies', Neuropsychiatric disease and treatment, 11: 1121-30.

Pickrell, Joseph K., Tomaz Berisa, Jimmy Z. Liu, Laure Ségurel, Joyce Y. Tung, and David A. Hinds. 2016. 'Detection and interpretation of shared genetic influences on 42 human traits', Nature Genetics, 48: 709-17.

Purcell, Shaun, Benjamin Neale, Kathe Todd-Brown, Lori Thomas, Manuel A. R. Ferreira, David Bender, ... Pak C. Sham. 2007. 'PLINK: A Tool Set for Whole-Genome Association and PopulationBased Linkage Analyses', The American Journal of Human Genetics, 81: 559-75.

Purves, Kirstin L., Jonathan R. I. Coleman, Sandra M. Meier, Christopher Rayner, Katrina A. S. Davis, Rosa Cheesman, ... Thalia C. Eley. 2019. 'A major role for common genetic variation in anxiety disorders', Molecular psychiatry.

Ramasamy, Adaikalavan, Daniah Trabzuni, Sebastian Guelfi, Vibin Varghese, Colin Smith, Robert Walker, ... Michael E. Weale. 2014. 'Genetic variability in the regulation of gene expression in ten regions of the human brain', Nature Neuroscience, 17: 1418-28.

Rayner, Christopher, Jonathan R. I. Coleman, Kirstin L. Purves, John Hodsoll, Kimberley Goldsmith, Georg W. Alpers, . . . Thalia C. Eley. 2019. 'A genome-wide association meta-analysis of prognostic outcomes following cognitive behavioural therapy in individuals with anxiety and depressive disorders', Translational Psychiatry, 9: 150.

Richter, N., G. Juckel, and H. J. Assion. 2010. 'Metabolic syndrome: a follow-up study of acute depressive inpatients', European Archives of Psychiatry and Clinical Neuroscience, 260: 41-49.

Sanchez-Roige, Sandra, and Abraham A. Palmer. 2020. 'Emerging phenotyping strategies will advance our understanding of psychiatric genetics', Nature Neuroscience.

Schmitt, Anthony D, Ming Hu, Inkyung Jung, Zheng Xu, Yunjiang Qiu, Catherine L Tan, . . Bing Ren. 2016. 'A Compendium of Chromatin Contact Maps Reveals Spatially Active Regions in the Human Genome', Cell Reports, 17: 2042-59.

Schwabe, I., Y. Milaneschi, Z. Gerring, P. F. Sullivan, E. Schulte, N. P. Suppli, ... C. M. Middeldorp. 2019. 'Unraveling the genetic architecture of major depressive disorder: merits and pitfalls of the approaches used in genome-wide association studies', Psychological Medicine, 49: 2646-56.

Smoller, J. W., O. A. Andreassen, H. J. Edenberg, S. V. Faraone, S. J. Glatt, and K. S. Kendler. 2019. 'Psychiatric genetics and the structure of psychopathology', Mol Psychiatry, 24: 409-20.

Spitzer, Robert L., Kurt Kroenke, Janet B. W. Williams, and Bernd Löwe. 2006. 'A Brief Measure for Assessing Generalized Anxiety Disorder: The GAD-7', Archives of Internal Medicine, 166: 109297.

Sullivan, P. F., M. C. Neale, and K. S. Kendler. 2000. 'Genetic epidemiology of major depression: review and meta-analysis', Am J Psychiatry, 157: 1552-62.

Thorp, Jackson G., Andries T. Marees, Jue-Sheng Ong, Jiyuan An, Stuart MacGregor, and Eske M. Derks. 2019. 'Genetic heterogeneity in self-reported depressive symptoms identified through genetic analyses of the PHQ-9', Psychological Medicine: 1-12. 
medRxiv preprint doi: https://doi.org/10.1101/2020.04.08.20057653; this version posted April 14, 2020. The copyright holder for this preprint (which was not certified by peer review) is the author/funder, who has granted medRxiv a license to display the preprint in perpetuity. It is made available under a CC-BY-NC 4.0 International license.

33

Turley, Patrick, Raymond K. Walters, Omeed Maghzian, Aysu Okbay, James J. Lee, Mark Alan Fontana, ... Consortium Social Science Genetic Association. 2018. 'Multi-trait analysis of genome-wide association summary statistics using MTAG', Nature Genetics, 50: 229-37.

Velicer, Wayne F. 1976. 'Determining the number of components from the matrix of partial correlations', Psychometrika, 41: 321-27.

Vigo, Daniel, Graham Thornicroft, and Rifat Atun. 2016. 'Estimating the true global burden of mental illness', The Lancet Psychiatry, 3: 171-78.

Vukasović, Tena, and Denis Bratko. 2015. 'Heritability of personality: A meta-analysis of behavior genetic studies', Psychological bulletin, 141: 769-85.

Walker, E. A., W. J. Katon, J. Russo, M. Von Korff, E. Lin, G. Simon, . . J. Unützer. 2000. 'Predictors of outcome in a primary care depression trial', Journal of General Internal Medicine, 15: 859-67.

Waszczuk, Monika A., Nicholas R. Eaton, Robert F. Krueger, Alexander J. Shackman, Irwin D. Waldman, David H. Zald, ... Roman Kotov. 2020. 'Redefining phenotypes to advance psychiatric genetics: Implications from hierarchical taxonomy of psychopathology', J Abnorm Psychol, 129: 143-61.

Watanabe, K., S. Stringer, O. Frei, M. Umicevic Mirkov, C. de Leeuw, T. J. C. Polderman, . . . D. Posthuma. 2019. 'A global overview of pleiotropy and genetic architecture in complex traits', Nat Genet, 51: 1339-48.

Watanabe, Kyoko, Erdogan Taskesen, Arjen Bochoven, and Danielle Posthuma. 2017. 'Functional mapping and annotation of genetic associations with FUMA', Nature Communications, 8: 1826.

World Health Organization. 2017. 'Depression and other common mental disorders: global health estimates'.

Wray, Naomi R., Stephan Ripke, Manuel Mattheisen, Maciej Trzaskowski, Enda M. Byrne, Abdel Abdellaoui, . . . the Major Depressive Disorder Working Group of the Psychiatric Genomics Consortium. 2018. 'Genome-wide association analyses identify 44 risk variants and refine the genetic architecture of major depression', Nature Genetics, 50: 668-81.

Young, J. F., L. Mufson, and M. Davies. 2006. 'Impact of comorbid anxiety in an effectiveness study of interpersonal psychotherapy for depressed adolescents', J Am Acad Child Adolesc Psychiatry, 45: 904-12.

Zinbarg, Richard E., Susan Mineka, Lyuba Bobova, Michelle G. Craske, Suzanne Vrshek-Schallhorn, James W. Griffith, . . . Deepika Anand. 2016. 'Testing a Hierarchical Model of Neuroticism and Its Cognitive Facets:Latent Structure and Prospective Prediction of First Onsets of Anxiety and Unipolar Mood Disorders During 3 Years in Late Adolescence', Clinical Psychological Science, 4: 805-24. 
Figure 1: Standardised factor loadings from a genetic exploratory factor analysis of 28 items of depression, anxiety and neuroticism.

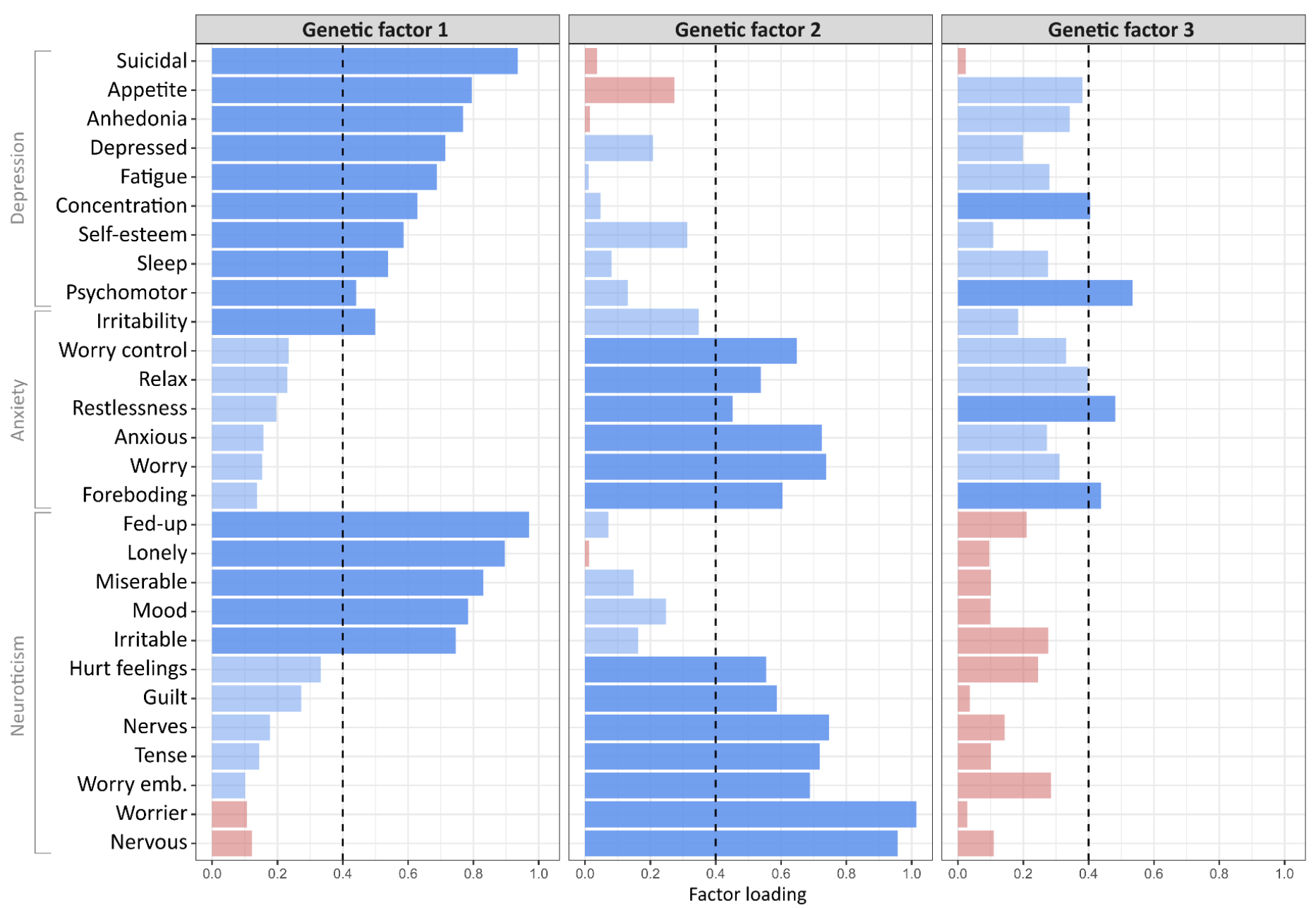

Note: Positive loadings are indicated in blue and negative loadings in red. Items with a standardised loading less than 0.4 are shown as transparent. 
Figure 2: SNP-based associations of the DEP and ANX latent factors and comparison of effect sizes

a

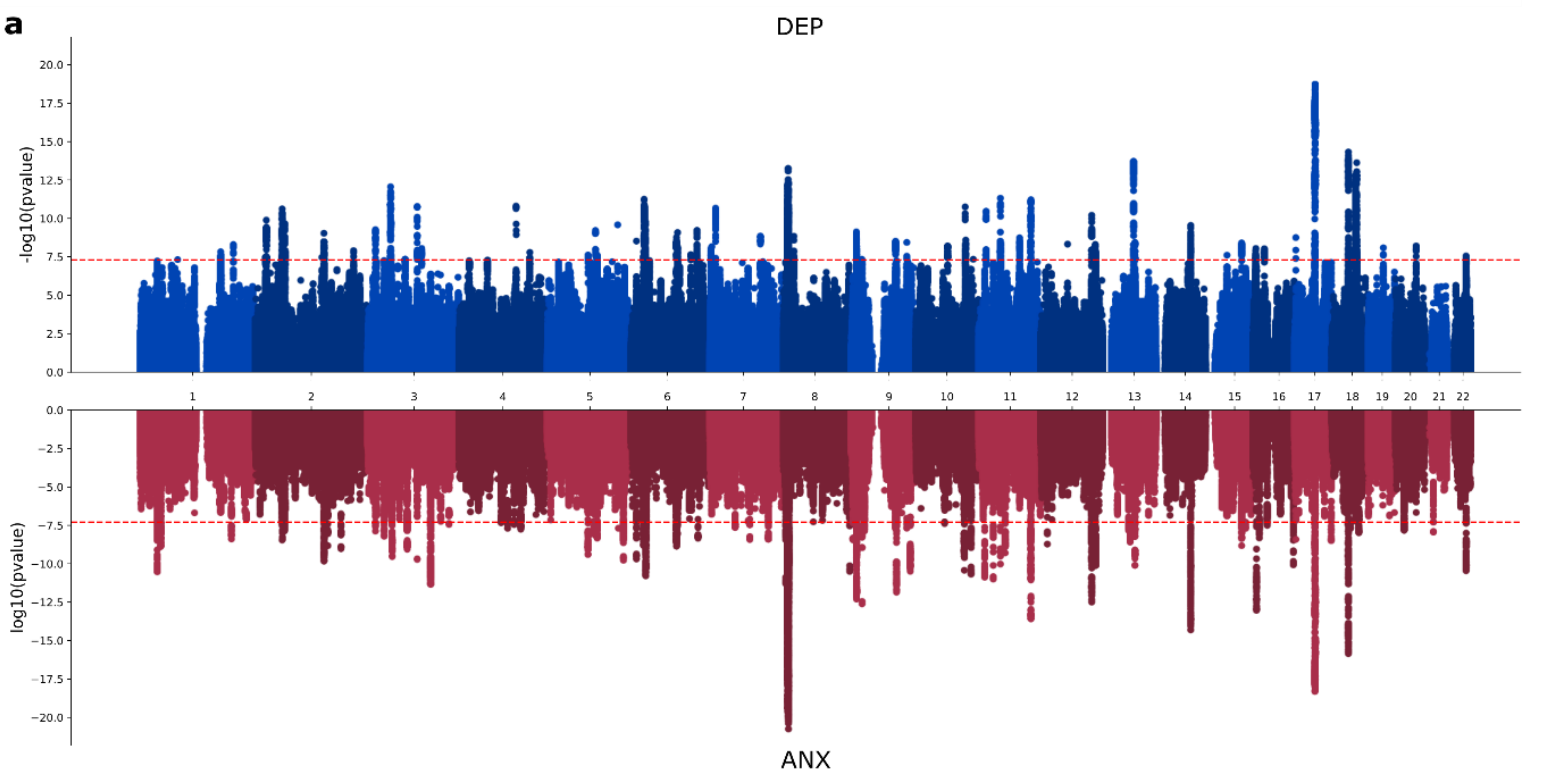

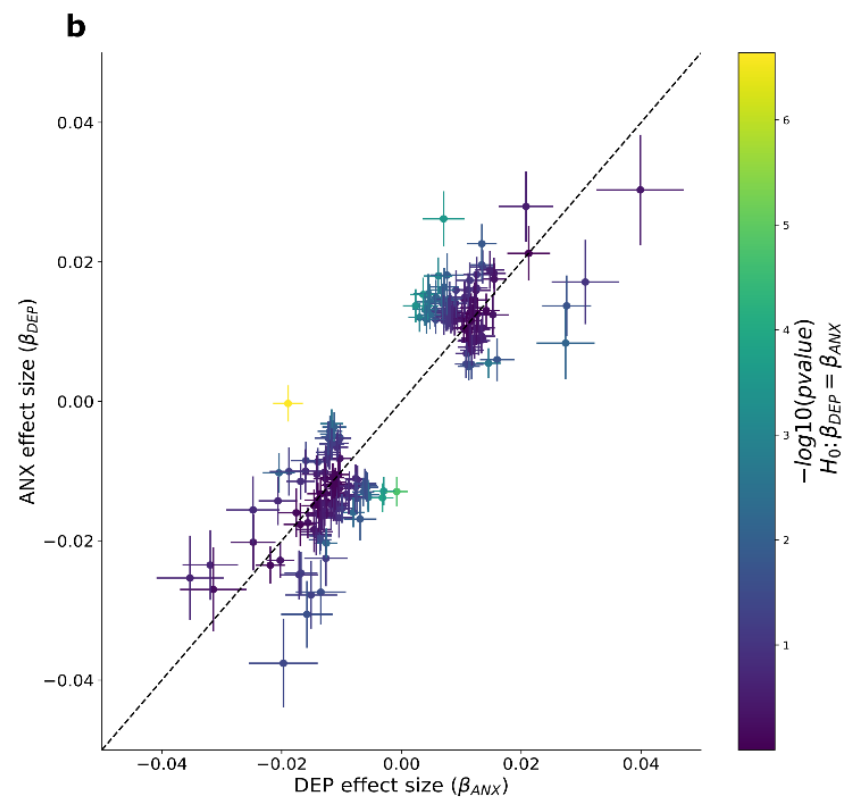

Note: (a) Manhattan plots for GWAS of the DEP (top; blue) and ANX (bottom; red) latent factors. The red line denotes the $p$-value threshold for genome-wide significance $\left(P<5 \times 10^{-8}\right)$. (b) Comparison of effect sizes for independent SNPs that reached genome-wide significance in the GWAS of either factor. 
medRxiv preprint doi: https://doi.org/10.1101/2020.04.08.20057653; this version posted April 14, 2020. The copyright holder for this preprint (which was not certified by peer review) is the author/funder, who has granted medRxiv a license to display the preprint in perpetuity. It is made available under a CC-BY-NC 4.0 International license .

36

Figure 3: Polygenic risk prediction of depressive and anxiety symptoms

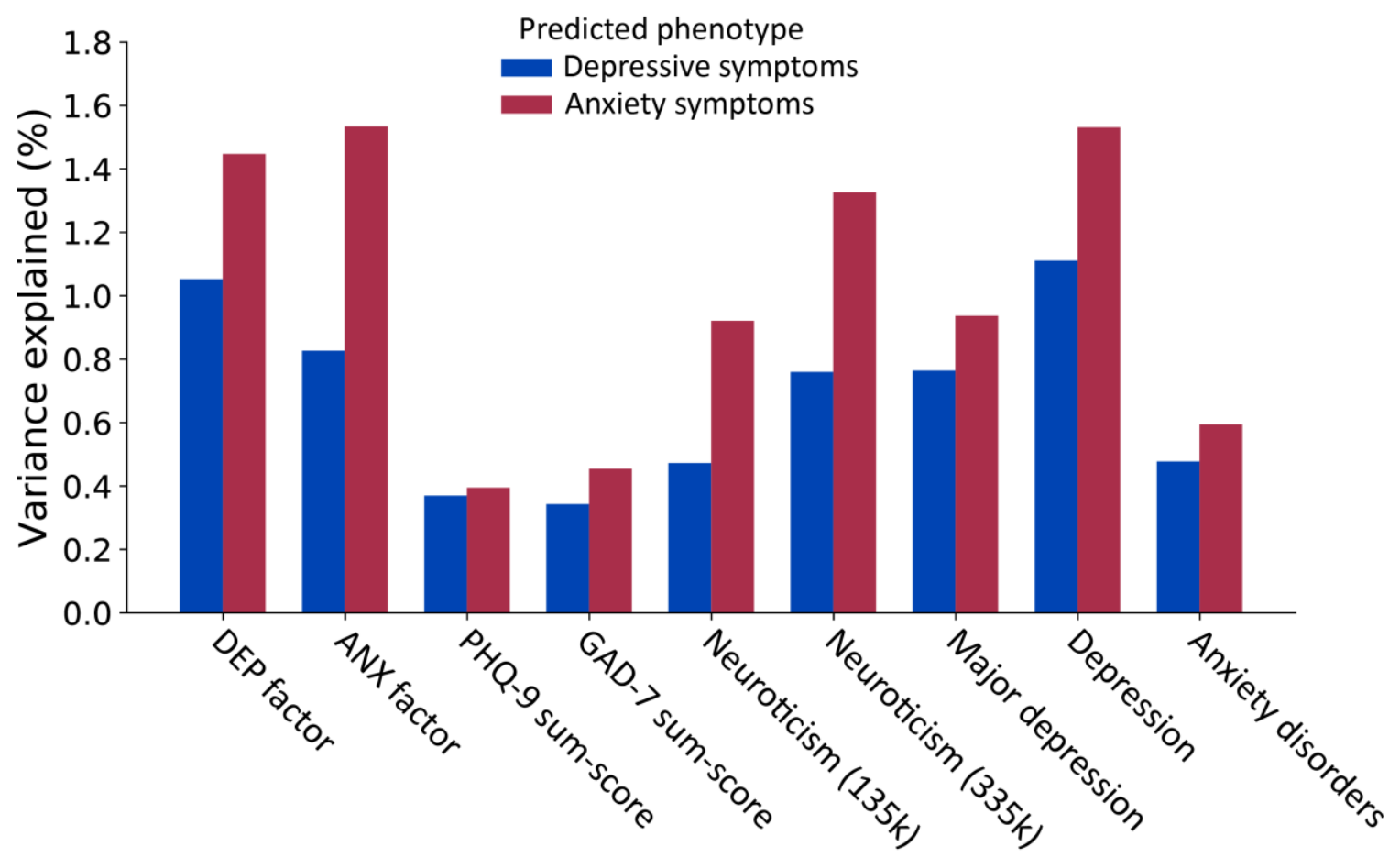

Note: amount of variance in depressive and anxiety symptoms explained by PRS for the DEP and ANX latent factors, and a range of related phenotypes: PHQ-9 sum-score ( $N=135,149)$, GAD-7 sum-score ( $N=135,747)$, neuroticism ( $N=136,212 ; N=338,812)$, major depression (Wray et al. 2018; QIMR and 23andMe cohorts excluded; $N=159,598$ ), depression (Howard et al. 2019; QIMR and 23andMe cohorts excluded; $N=494,258)$, and anxiety disorders ( $N=$ $114,019)$. All PRS predictions were significant after Bonferroni correction $(\alpha=0.05 / 18 ; P<$ $\left.2.78 \times 10^{-3}\right)$. 
medRxiv preprint doi: https://doi.org/10.1101/2020.04.08.20057653; this version posted April 14, 2020. The copyright holder for this preprint (which was not certified by peer review) is the author/funder, who has granted medRxiv a license to display the preprint in perpetuity. It is made available under a CC-BY-NC 4.0 International license.

37

Figure 4: Genetic correlations with other complex traits

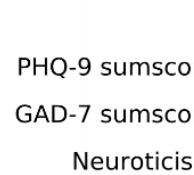

Major depression (Wray et al. 2018)

Depression (Howard et al. 2019)

Lifetime anxiety disorder

Obsessive compulsive disorder

Schizophrenia

Bipolar disorde

Attention deficit hyperactivity disorder

Anorexia Nervosa

Insomnia

Loneliness

Smoking Initiation

Age of smoking initiation

Cigarettes per day

Smoking cessation

Alcohol dependence

Alcoholic drinks per week

Lifetime cannabis use

Body mass index

Townsend deprivation index

Household income

Educational attainment

Intelligence

Subjective well-being

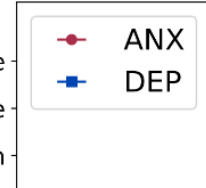


medRxiv preprint doi: https://doi.org/10.1101/2020.04.08.20057653; this version posted April 14, 2020. The copyright holder for this preprint (which was not certified by peer review) is the author/funder, who has granted medRxiv a license to display the preprint in perpetuity. It is made available under a CC-BY-NC 4.0 International license.

Figure 5: Shared and trait-specific genetic influences on depressive and anxiety symptoms.

a

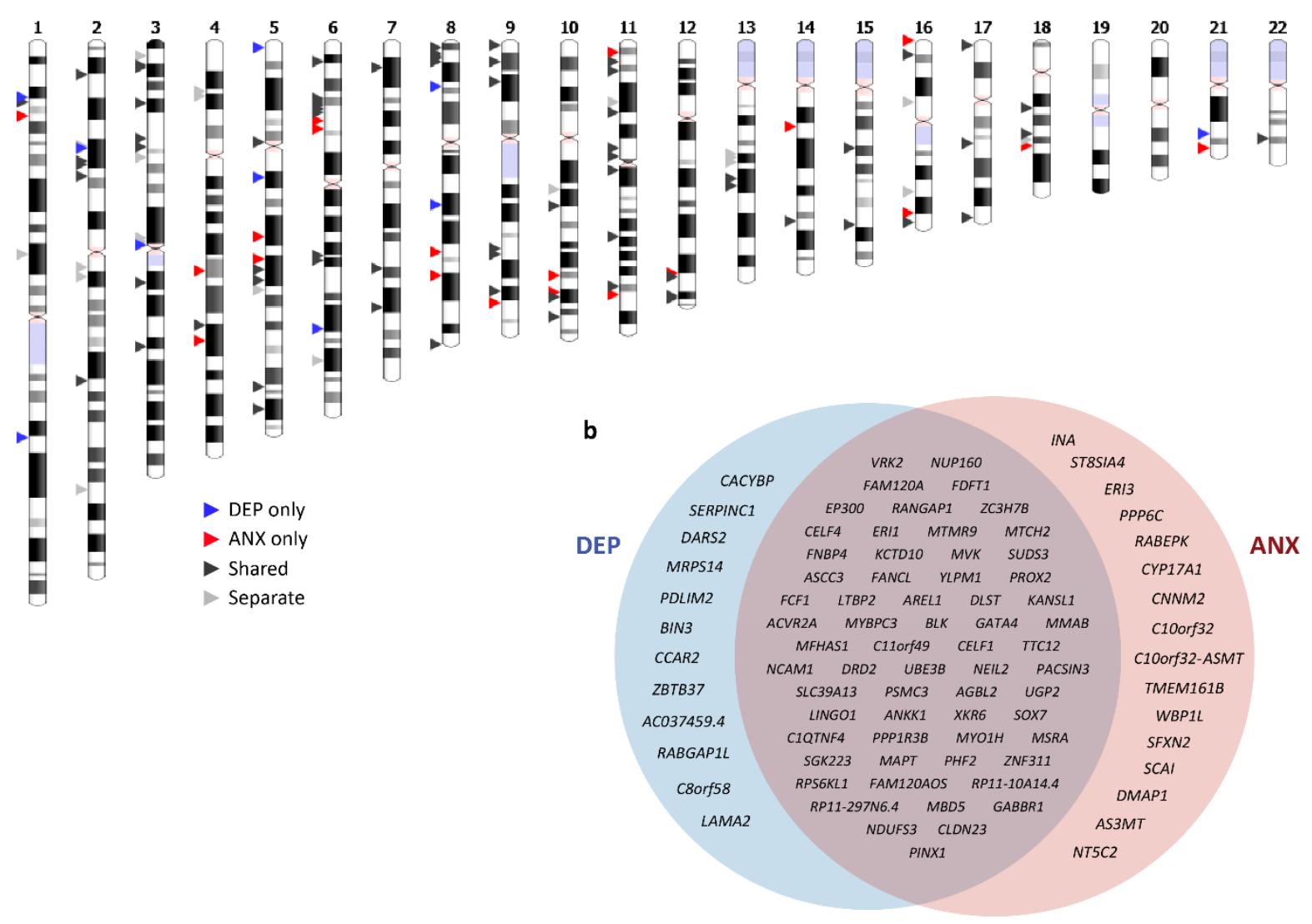

Note: (a) Genomic regions that are specific to DEP (blue arrows), specific to ANX (red arrows), shared (dark grey arrows), or influence both traits via separate variants (light grey arrows). (b) Prioritised genes for shared and trait-specific regions. Genes that reached significance (after Bonferroni correction) in the gene-based test and were identified by at least two additional methods (position, eQTL, or chromatin interaction) are presented (see Supplementary Tables 15-20 for all mapped genes). 